\author{
Müller, Retief ${ }^{1}$ \\ Keimyung University
}

\title{
Inner interreligious dialogue in global Christianity - a consideration of case studies from Korea and Southern Africa
}

\begin{abstract}
This article discusses the issue of plurality in world Christianity. Considering two contemporary contexts, South Korea and Southern Africa, this article claims that the interreligious pluralities as evidenced in much of contemporary Christianity are to be understood in continuity with some of the foundational experiences of the early church, especially in the city of Antioch. This plurality, which can also be described as hybridity, acquires intercultural theological significance when understood as inner interreligious dialogue. This is further described as a mostly subconscious process by which contemporary Christians continue to engage with their pre-Christian traditions. From a phenomenological point of view this process is demonstrable in Christian history. Theologically speaking it has the potential to debunk myths of Christian 'purity' and to expose fundamentalists' assertions of their own 'orthodoxy' as tantamount to wishful thinking. Finally, this article makes the case that this process of inner interreligious dialogue, when brought to the surface may positively enhance the quality of real outward dialogue with representatives of other faiths or systems of belief and value.
\end{abstract}

\section{INTRODUCTION}

This article starts with the premise that world Christianity has been, and continues to be characterized by a great deal of plurality, which is also described as hybridity. The thesis is that hybridity, within the context of religion may be further conceptualized as inner interreligious dialogue. I will show how and why this might be the case, relying on examples from history and personal cross-cultural experiences of contemporary global Christianity. Although hybridity tends to occur beneath the surface of official ritual and doctrine, I will argue that active acknowledgement of inner interreligious dialogue should naturally enhance the quality of interfaith dialogue proper between Christian communities and adherents of other religions/ systems of belief.

Some thoughtful theologians in Christian history have attempted to address seriously the paradox that is at the heart of the Christian message. Paradox in Christianity functions at many levels, but it all springs from the central story of Jesus and especially the implications of the broken body of the saviour at the cross. For example cf. Andrew Kirk, who puts the matter succinctly: 'This is the amazing paradox of the drama: God was condemned for blasphemy against God: "He sought total and complete liberation for humanity, and we condemned him as subversive of the established order"' (Kirk 2000: 53). This fundamental paradox seems to set in motion a dialectical interplay of paradoxical truth, which has been the subject of much

1 Retief Müller is Assistant Professor in Christian Studies at Keimyung University, Daego, South Korea, and Research Fellow of the Department of Practical Theology, University of Pretoria. 
theological treatise. Although, it is possible to make too much of paradox on the one hand, on the other it could be argued that the theme should be carried even further afield. Therefore, this article will illustrate that a certain kind of paradox has not only value for Christian theology, but also for interpreting World Christianity from a phenomenological point of view.

One of the greatest phenomenological paradoxes in Christian history is the fact that for a religion with fairly exclusivist claims regarding adherence to its central paradox as mentioned above, Christianity has been remarkably open to all kinds of pluralisms. The empirical reality of contemporary world Christianity provides some interesting possibility for studying the extent of this plurality cross-culturally.

\section{PLURALITY, HYBRIDITY, AND INNER INTERRELIGIOUS DIALOGUE}

In what follows I will provide some examples of what I mean by plurality in World Christianity. I believe that this plurality could be more narrowly defined by the word 'hybridity', which I prefer to the more ideologically loaded term, 'syncretism'. Not that hybridity is without problems either. It stems from biology and was subsequently appropriated, but not universally endorsed, by scholars working in postcolonial studies (cf. Brah \& Coombs 2000). More recently it has occasionally been used in theology and religious studies (e.g. Jang 2006; Kenzo 2004; Müller 2008; Scott 2004). Even in these latter disciplines the term has been used in widely divergent frameworks of reference. Therefore, appearances aside the term hybridity is not self-explanatory.

My usage of the term generally relates to the paradoxical way in which fully committed Christians may be seen to live out their faith in ways that sometimes rely quite heavily on religious traditions that are usually understood to be totally alien to Christianity, i.e. those which are not counted amongst the Abrahamic faiths.

I argue that these 'paradoxical' hybridities should be interpreted as instances of inner interreligious dialogue. By this I mean an unspoken, mostly unacknowledged interchanging and sorting out of divergent religious ideas within the public ritual and discourse of particular Christian communities. As such it is different from intrareligious dialogue as understood by Peter Phan for example. 'Intrareligious dialogue', which has also been described as communicatio in sacris, refers to an internal, personal encounter between different religious traditions. The person experiencing this is consciously aware of doing so, allowing the different traditions to 'interact', remaining open to new insights, transformations and so on (Phan 2003: 511).

Inner interreligious dialogue on the other hand is an accidental rather than an intentional dialogue. It might even be termed subconscious as opposed to conscious. It is tempting to compare it to talking in one's sleep, which would not be wholly inappropriate in the light of the fact that dreams and visions have often been the mode through which religious revelation has occurred, also in the history of Christianity. Given the cultural particularity of all Christian communities, each informed by specific religious and cultural backgrounds, this kind of 'dialogue' is unavoidable.

By calling it unavoidable I do not wish to resurrect a deterministic view of religious change, such as the once famous/notorious thesis initially posed by Robin Horton in his 'African Conversion' article (Horton 1971). Horton argued that the monotheistic religions of Christianity and Islam merely served as catalysts for a process that was already underway in West Africa. According to Horton, colonialism had exposed the local people to a wider macrocosm, which also triggered a religious movement away from local spirits and deities, focusing instead on one Supreme Being as representative of the macrocosm. Therefore, their acceptance of either Christianity or Islam was an inevitable response in making intellectual sense of a wider macrocosm. Horton's theory has been criticized for being overly mechanistic, but also simplistic in its review of West 
African history, which had not been as micro-cosmic as Horton assumed it to be prior to the arrival of colonialism. Furthermore, such a one-directional and absolute movement from the local religions to the world religions, as assumed by Horton's theory would leave little room for the possibility of participating in the kind of internal dialogue, which I suggest is happening in world Christianity. Even though one might agree that communities and individuals are somehow forced to reconsider their cosmologies when their world suddenly and dramatically changes due to outside incursions, the conclusions they would draw are actually not as pre-determined as an outsider might be tempted to think. All one can say for certain is that a new internal dialogue/ debate would start to occur at this point.

\section{SLEEP-TALKING AND THE NEED TO WAKE UP}

The reality is that the individuals and communities themselves determine the extent to which participation occurs in this internal dialogical process. They can either engage with the process underneath the surface, in the way that an individual would often 'sleep on' a problem in order to help solve it. Or, they can wake up to it, and consciously engage with the process. Due to the doctrinal constraints that religious communities often place upon themselves, this second option is usually not a realistic possibility.

Whatever they choose, they do not have the option to entirely disengage from it. Anthony Giddens (quoted in Kenzo 2004: 249) states: 'Human beings produce society, but they do so as historically located actors, and not under conditions of their own choosing'. Similarly, I could add that although religious communities construct their own religious cultures, they also do so under the weight of their tradition, within the limitations and constraints of their particular communities, on the one hand. On the other hand, they also construct their religions within the scope of their surrounding cultural environments, which include other, competing religions, and/ or secular worldviews, ideologies, etc. The boundaries between religious communities and those surrounding cultures are often more porous than both insiders and outsiders might assume. It is not unlike some of the borders separating nation-states in our day and age. Jonathan Tran, for example, has well deconstructed some of the myths of 'purity' that underpin the 'globalized nations-state', and its obsession with borders (Tran 2008). Therefore, in terms of Christianity a degree of natural cross-fertilization occurs, which I variously refer to as hybridity and inner interreligious dialogue.

It is a premise of this article that the eventual waking up to inner interreligious dialogue may be a critical preparatory step towards engaging in proper interfaith dialogue across the various divides that separate and alienate communities from each other.

The ability to 'wake up' or not, might well be influenced by the relative degree of cultural and/or linguistic isolation/integration of the particular community in question. For example, I would not be surprised if communities that are exposed to more than one language and possibly even bi- or multilingual themselves, might also be more tolerant of their own hybridities on the religious and cultural levels. The early church possibly lends us a clue in this direction.

\section{SETTING THE TONE: EARLY CHRISTIANS IN ANTIOCH}

Peter Phan describes the early church as an example of what he calls 'multiple religious belonging'. Phan's emphasis is different from mine in that the kind of 'multiple religious belonging' that he discusses and advocates concerns the active, conscious attempt to combine in one's own life, different religious perspectives (Phan 2003). This is what Phan understands to be the case in early Christianity, with adherents confessing their faith in the Risen Christ, while at the same 
time continuing to be fully participating Jews (Phan 2003: 404-5).

I agree with Phan that the early church is significant, but in my focus on 'hybridity' rather than 'multiple religious belonging', I think that the relevant group should be more closely described. This I argue because I do not believe the majority of early Jewish Christians had any notion that they had joined a new religion. They understood themselves to be firmly under the umbrella of Judaism, and their belief in Jesus of Nazareth as the Messiah was fully justified and interpreted within the context of that tradition. The ones who were really attempting to negotiate divergent religious streams were those who made a conscious effort to include Gentiles into their circle. Focusing on this smaller group also gives one the opportunity to address the potentially crucial role of language and its relationship to religious formation.

Therefore the earliest Christians in Jerusalem and surrounding areas were not significant for the fact that they were also Jews. From their point of view there was nothing 'out of the box' about that. In fact, it was normative. When the church in Antioch decided to open its doors to Gentiles, however, and specifically under conditions that meant the new Gentile converts did not have to become Jews, something surprising was happening (cf. Tomkins 2005:17-18). The fact that Gentiles wanted to join a Jewish sect might have seemed out of the ordinary, but what was even stranger was that the Jewish insiders agreed to compromise seemingly 'essential' elements of their own tradition as prescribed by the Law of Moses. Therefore, what made the events at Antioch significant was not that Gentiles were becoming Christians in droves, but that the Jewish Christians were seemingly going out of their way to make it possible for Gentiles to do so by dispensing with food taboos, and especially with the ritual of entrance into Judaism, circumcision. This perspective was finally endorsed by the Jerusalem Council according to Acts 15 in the Christian New Testament.

In fact, I would argue that these Antioch-based Jewish Christians represented an early example of precisely what I mean by inner interreligious dialogue. They were Greek speaking Jews of course, distinct from the Aramaic speakers who represented the majority in the Jerusalem church (Tomkins 2005: 14ff).

The Greek speakers had escaped Jerusalem under persecution after suggesting that belief in Christ superseded the ritual requirements of the Law of Moses. Their linguistic preference for Greek is significant because it means that they probably grew up in a cross-cultural setting, as opposed to the Aramaic-speaking natives of Jerusalem. They were intimately familiar with the religious cultures of the Greco-Roman world as well as the Jewish tradition of their ancestors. Contrary to the Aramaic native speakers in Jerusalem who were probably fairly mono-cultural and monolingual with little incentive to become fluent in Greek, one could also assume that these Greek-speaking Jews in places like Antioch had more than a rudimentary knowledge of the language of their ancestors. At the very least, they might have been good examples of cultural 'hybridity' long before the term itself was invented.

Of course much of the above is conjecture, but it is conjecture based on the evidence of the relative ease with which the Antioch Christian community seemed willing to cast aside the 'yoke' of the Law of Moses. In contrast to the Aramaic speaking Jerusalem Christians, this group understood Christianity as a system of belief surrounded by soft, permeable boundaries.

It has been said that the decision by the Antioch Christians to throw open wide their doors to Gentiles, had set the tone for subsequent cultural crossings of the Christian gospel. Andrew Walls, for example, describes the Antioch situation as "one of the most critical events in Christian history." Walls further points out that the Antioch Christians used the Greek term, Kyrios (Lord) in reference to Christ, the same term that was used for the Pagan deities (Walls 1996:

52). Therefore, acknowledging the linguistic aspect in the process, this penchant for hybridity has been described as the 'translatability of the gospel'. I tend to agree with the scholars who 
emphasize the 'translation principle' in Christian history, the most notable names being those of the missiologist-historians Lamin Sanneh (1995) and Andrew Walls (1996, 2002). However, important as both cultural and linguistic translation are in the process of ongoing religious change, it seems obvious that an acknowledgment of hybridity as an attempt to describe the interwoven nature of divergent religious perspectives within Christianity provides a further necessary tool for analysis and interpretation.

\section{HYBRIDITY IN CONTEMPORARY CHRISTIANITY}

Having personally encountered divergent strains of global Christianity in cross-cultural settings, this kind of hybridity has become central to my research over the past few years. I will refer to two different contexts from the point of view of participant observation.

The two contexts concerned are South Korea and Southern Africa. Geographically and culturally these two contexts are 'worlds apart' in almost all the possible meanings one might wish to attribute to that term. Yet, in both contexts significant proportions of the population describe themselves as Christian. This is especially true for Southern Africa, which as part of sub-Saharan Africa, generally, increasingly finds itself in Christianity's demographical 'centre of gravity' as described by Andrew Walls (1996, 2002), for example. South Korea, on the other hand, has a minority of Christians, less than a third of the population. But within the wider context of East Asia, the successes of both Protestants and Roman Catholics in attracting members are noteworthy in South Korea.

\section{English language and Korean Christianity}

One of the first things the religiously interested newcomer to South Korea will notice is the plethora of red neon crosses that contribute to the illumination of the night sky. Nestled alongside other 'businesses' that jostle for customers, Christian churches seem to find themselves tapping into a similar consumer driven ethos as they compete for members through evangelistic campaigns that resemble the advertising campaigns of some secular enterprises.

Choosing a church to call one's spiritual home among the many might not be an easy decision for the Korean faithful, but for the English speaking foreigner it is a somewhat more straightforward decision given the relative paucity of available options in English. Therefore, after arriving in Korea in early 2006, my wife and I relatively quickly found ourselves drifting to an English worship service jointly conducted by a pastoral couple of mixed nationality: a Korean woman and her Canadian husband.

This worship service in the heart of Seoul posed some interesting theological conundrums, especially when evaluated from the point of view of reformed theology. Reformed theology typically insists on the centrality of the Word, and that is the perspective an outsider might be expecting when joining a worship service in a Presbyterian church anywhere in the world. However, the distinct impression I had after first attending this particular English worship service in Seoul was that although words seemed to be a major focus of proceedings, these only incidentally concerned the Word of the Christian Gospel. Rather the emphasis seemed to be on the words making up the English language. Particular care seemed to be given to their correct intonation and pronunciation.

The attendants at the service were Korean children for the most part, in some cases accompanied by their parents. It soon became obvious that they were there for the purpose of learning English. Therefore, an integral part of this worship service was the weekly introduction and memorization of 'new words'. It was notable that compared to the rest of the service the 'new words' part of the liturgy generated by far the most interest and participation. 
What at first seemed like none other than an English language academy under the guise of Christian worship, turned out to be a somewhat more complex situation after a conversation with the Canadian pastor. It emerged that they had been sent as missionaries by their home church to minister in the service of the host congregation in Korea. Upon their arrival they discovered that although there was no shortage of pastors in Korea, there was a real thirst for English and seemingly not enough individuals with the skills to teach it. Therefore, they were conscious of the fact that their greatest asset was their English proficiency. If free English lessons were to be the main reason for the popularity of their worship service, then they would not be disdainful of that reality.

Notwithstanding the fact that missionary endeavours have always been characterized by involvement in secular activities such as education, and medical services, what is of interest here is the apparent synthesizing of Christianity and English language education in the form of the English worship service.

In order to better understand the situation, some comments about the background of Korean Christianity may be useful, particularly concerning the lingering influence of Confucianism on all of Korean society, including Korean Christianity.

\section{CONFUCIANISM IN THE BACKGROUND}

Confucianism is assumed to have been introduced to Korea, 'sometime during the Period of Warring States in China (B.C. 403-221)' (Keum 2000: 34). It was especially influential in the foundation and reign of the Choson dynasty (1392-1910). The Neo-Confucianism school (Tohak), which was representative of Korean Confucianism during much of this time, was a movement with exclusivist claims over against the older presence of Buddhism. Neo-Confucianism could convincingly be called the state ideology of the Choson Kingdom (Keum 2000: 38).

Despite the exclusivist tendencies of Neo-Confucianism, and the enduring cultural significance of the Choson dynasty as historical backdrop for modern Korea, it would be a mistake to assume complete hegemony for Confucianism during this period. Keum Jang-tae calls it, 'one of the three pillars of Korea's religious tradition' (Keum 2000: 33), along with Buddhism and Taoism, the latter being more recently replaced by Christianity.

For my purposes here, there is one aspect of Confucianism that needs to be particularly stressed. In its influence on Korean society, Confucianism has always emphasized education. The Confucian concept of education sees learning as a vital process in the cultivation of a person's character. Keum Jang-tae, states: 'Education in Korea had its roots in Confucianism, and Confucian ideas had a decisive impact upon the aims, methods, and curriculum of schools' (Keum 2000: 33).

Within a tightly knit society such as Korea a degree of intermingling between the various religious traditions seems inevitable, and with Confucianism being the dominant tradition for a long period, it seems natural that it would have played a role in the indigenization of particularly Christianity, being a more recent introduction on the Korean peninsula (Cf. Oak: 2006). Such an assumption gains further credence when one considers the fact that Christianity was first introduced to Korea by Su-Gwang Yi (1563-1628), one of the Choson dynasty's diplomatic envoys to China. He was also a Confucian scholar who had come into contact with the work of the Jesuit missionary, Matteo Ricci. Su-Gwang Yi brought Ricci's book T'ien-chu Shih-I (The True Meaning of the Lord of Heaven) back to Korea (Kim 2002: 71). Since Ricci had purposefully striven to avoid giving offence to Chinese Confucianism, his book, along with others in a similar vein, were also well received by Korean Confucian scholars, interested in 'Western Learning'. Through exposure to works such as these, Korean scholars, who belonged to the Practical Learning (Sirhak/ 실학) 
school, had by the middle of the eighteenth century become interested in Catholicism (Oh 2006: 372).

For what follows two related aspects from the above should be highlighted: 1) the general importance of learning and education in Korean Confucianism; and 2) the fact that Christianity was first introduced to Koreans by Confucian scholars as a system of learning.

Although the 'West' that the Sirhak scholars were interested in learning more about was no further west in relation to Korea than contemporary China, it is noteworthy that when the new 'West' in the shape of American missionaries arrived towards the end of the nineteenth century, they also centred much of their activities on the issue of learning. Many of the prominent Korean institutions of higher education hark back to this period with their roots in these missionary endeavours. By focusing their attention on educational services and modern medicine, it seems these missionaries had tapped into exactly the right vein. As James Huntley Grayson states: 'Much of the success of the Protestant churches in the first twenty-five years after the arrival of the missionaries reflected the association of Christianity with the "progressive" West and the emphasis that the first generation of missionaries placed on the responsibility of local Christians for the growth and support of their churches' (Grayson 2006: 13-14).

This association with and interest in the West, progressive or not, still seems to be a feature of contemporary Korean Christianity. At crucial points in its history, Korean Christianity also managed to encapsulate the ethos and the aspirations of the nation at large. Examples include Christians' contributions to the Korean independence movement under Japanese occupation, their association with Korean nationalism, as well as the involvement in the re-unification movement following the division of the peninsula between North and South.

In recent years one of the most lucrative growth sectors from a business point of view has been in the field of English language education. Korea has become 'crazy for English' it is sometimes said. In terms of social stratification, the so-called digital divide, is progressively being eclipsed by the 'English divide.' English proficiency has become one of the most important factors in terms of finding white-collar employment. Hence, there has been a massive government sponsored push to promote English language education at all levels. 'Native' English speakers, with a preference for North Americans, have been recruited to teach English in schools, universities and private academies. Given their history of representing the general societal aspirations it should come as no surprise that Korean churches should also give their attention to this more contemporary cultural drive.

\section{INNER INTERRELIGOUS DIALOGUE IN KOREAN CHRISTIANITY}

During the last few years I have been able to reassess my initial exposure to the English worship service in Korean Christianity. I have been involved in the ministry of English worship at a church in the city of Daegu. The worship pattern and liturgy show strong resemblances to what I had initially encountered in Seoul. Again the focus is on children. Again the concern of parents and teachers involved in the service would seem to prioritize English learning as the primary motivation for what we do.

Having an English worship service seems to lend something of a competitive edge over other churches that do not provide this service. Several different Korean pastors attempting to recruit me to this end have approached me, and I know that other church-going foreigners, with or without theological backgrounds, are recruited as a matter of course to become involved as preachers and teachers in English worship.

When one considers oneself a theologian and scholar of religious history, one might easily feel slighted at being thus converted into an English teacher by the Korean church setup. However, 
when hybridity is taken into account, it soon becomes apparent that this could be an example of misplaced frustration. What is necessary is to uncover the underlying thread, which explains the rationale. In the case of Korean Christianity that thread, as explained by Young-Gwan Kim among others, is that it 'cannot avoid the religio-cultural legacy of Confucianism' (Kim 2002: 81).

When God is beseeched to help in the improvement of children's English, as is often the case during prayer times at these worship services, then one might do worse than to interpret it along the lines of the primary goal of Confucianism, summarized by Keum Jang-tae as 'cultivating one's potential to become a sage' by way of a process 'called "teaching" or "learning"' (Keum 2000: 81).

Taoism, the influence of which in Korea has waned since the introduction of Christianity, seeks to uncover truth by focusing on that which is negative. Confucianism, on the other hand, with its enduring influence in Korea, 'proceeds through a positive process of accumulating "learning", building a little at a time, until one reaches the level of sage' (Keum 2000: 81). Although 'learning', would include 'the investigation of the ultimate being', that is only part of the goal. Additionally: '"Learning" is a process for pursuing the Confucian ideal, perfection of self' (Keum 2000: 82). It is perhaps significant that language learning seems very much suited to this approach of 'building a little at a time', especially in terms of the memorization of vocabulary.

Therefore, when language study occurs within the context of religion in contemporary Korea, one would expect it to specifically occur in the context of Confucianism. However, on the contrary this is exactly what seems to be happening in the 'English worship service' in Korean Christianity. An activity called 'Bible Game' might even be said to be indicative of the hybridizing of additional religio-cultural vectors. In this eagerly anticipated activity occurring towards the end of the service, children get the opportunity to recite memorized texts from Scripture, the Apostle's Creed and so on. They are rewarded with 'Talents' according to how well they were judged to perform by the teacher in charge of the activity. 'Talents' is a Korean Christian version of Monopoly money. But unlike the money used in Monopoly, 'Talents' actually also function as real currency, used to buy toys and other goods that are put up for sale at 'Talent parties', which occur a few times every year.

Whereas the emphasis on rote memorization and recitation of Scripture might be partly explained by the lingering influence of Confucianism, the way the 'Talent' system functions is more reminiscent of kiboksinang (기복신앙), with its roots in Korean Shamanism, which has a 'this-worldly' focus in its expectation of material blessings in return for ritual appeasement. According to Hyung Chull Jang (2006), a Christianized version of kiboksinang was 'highly instrumental' in the numerical expansion of Korean Protestantism between the 1960's and 80's.

Jang, who discusses these and other aspects of 'cultural hybridity' in Korean Protestantism, however, focuses on the interconnectedness between Christianity and modernization rather than the specific inter-religious aspects of hybridity. Although the inter-religious aspects seem fairly obvious when considered from an outsider perspective, insiders might be less likely to mention these, because, paradoxically, Korean Protestantism tends to strongly identify with Evangelicalism (Lee 2006: 330), with its generally uncompromising stance towards other religions. This situation, however, is exactly what one would expect in inner interreligious dialogue. More than one religious traditions are active, but underneath the surface rather than openly acknowledged.

\section{Southern African Christianity and the 'Man with the Key to the Rain'}

During research on the role of pilgrimage in Southern African Zionist Christianity (Müller 2008), I found interesting examples of inner interreligious dialogue between Christianity and African Traditional Religion. It is particularly well illustrated in the focus on rain as symbol for well-being 
and divine blessing.

While this issue cropped up periodically during my research it came to a specific head at Gaborone, Botswana during a visit of the Zion Christian Church's Bishop Barnabas Lekganyane and thousands of his church members, who followed him there from South Africa in November, 2005. The Bishop's visit was specifically for the purpose of 'praying for rain.'

Rain is of course a precious commodity in Botswana, as indeed in much of Southern Africa. The Botswana national currency is Pula (lit. rain), which well captures the sentiment. But the country was experiencing a severe drought at the time, hence the need for divine intervention. Bishop Lekganyane with his well established reputation for praying successfully for rain created quite a stir among the local population, including in the Botswana news media. On a number of occasions I heard my pilgrimage companions, all of them ZCC members, refer to their church leader as the 'man with the key to the rain'.

Historically, there has been a tendency among church members to identify connections between and competitively compare the 'rainmaking' abilities of Lekganyane with those of the geographically and culturally related Modjadji, queen of the Lovedu (See Krige and Krige 1943). Of course, the latter's rain rituals proceed purely from the point of view of Traditional African Religion, whereas Lekganyane is a Christian church leader (Van Wyk 1986: 417; Nchabeleng 1983: 101). To make the claim that the Lekganyane dynasty is more efficacious in this respect, as ZCC members have tended to do is quite extraordinary in the light of the received wisdom, which states: 'The Lovedu queen is renowned as the greatest rain-maker in South Africa ...' (Parrinder 1976: 80).

In water-starved Botswana, one would expect the religious preoccupation with rain to be even stronger than in northern South Africa, and although the Batswana people could never claim a rainmaker of equal renown to Modjadji, anthropologist Isaac Shapera clearly showed how the procurement of rain was very much a subject of ritual in their traditional society. Just as elsewhere in Southern Africa, the roles of king/queen and head priest/priestess tended to converge, and according to Shapera a ruler's performance evaluation often hinged on their perceived ability (or inability) to bring rain (Schapera 1971: 133).

Therefore, it is perhaps no surprise that the subsequently Christianized people of this dry region with their relative dearth of historical and contemporary rainmakers would opt to invite what I will cautiously call a contemporary Christianized version of Modjadji to perform the rituals that could bring the rain. One thing the contemporary peoples of southern Botswana and South Africa's Limpopo province have in common apart from their historical linguisticcultural relatedness is after all Christianity, and specifically the transnational presence of the Zion Christian Church.

In the case of Bishop Lekganyane, the expected rituals seemed to be none other than his public appearance and prayers in the context of a Christian worship service, although I have witnessed how his very presence in Gaborone was interpreted as efficacious. This became particularly evident when much rain fell during the night preceding the Bishop's sermon at the local sports stadium.

The morning after the rains had fallen my companions shared with me all manner of faith confessions, in which the question of the Bishop's possible divine status came to the fore. Indeed, perhaps indicative of ongoing inner interreligious dialogue, one of my companions made contradictory statements regarding his belief in the Bishop's 'divinity' over the seven-month period I had contact with him. On a previous occasion he had forcefully disputed any such a notion, but after the Gaborone rains fell, he approached me with questions, which seemed to indicate a change of mind, expressing the sentiment that the Bishop might be 'a god' after all.

The tendency towards the deification of the ZCC bishop is particularly interesting as a case 
of hybridity in the light of the fact that a traditional title for chiefs among the Pedi, to which the Lekganyane clan belongs, is modimo wa lefase (Mönnig 1967: 56), which loosely translated means god of the earth.

Therefore, similar to the case of Korean Protestantism, the Zion Christian Church, which with its millions of adherents has become somewhat representative of indigenous Southern African Christianity, seems to be drinking from the fountains of pre-Christian religious traditions. But also in their case, much of this inner dialogue takes place beneath the surface. Although they make a serious effort to openly emphasize their Africanness, from their point of view they are a Christian church, 'just like any other church'.

Bishop Lekganyane is not by any means the first Christian leader to step into the role of 'rainmaker'. Other contemporary church leaders, both black and white, routinely engage in rain prayers. The precedent was laid by some of the early $19^{\text {th }}$ century European missionaries, whose rain prayers were often perceived and evaluated in terms of competition with the traditional rainmakers by potential converts (Cf. Chidester 1992: 40). Although the London Missionary Society's Robert Moffat, among others, eschewed the practice, certain other missionaries, such as Johannes Van der Kemp, saw it as their pastoral duty to pray for rain when their congregation members demanded it. They seem to have conducted an effective ministry in as much as their prayers were seen as 'successful' (Hastings 1994: 315).

Therefore, Bishop Lekganyane and other contemporary church leaders in Southern Africa who periodically pray for rain are simply building forth on a hybridity into which some colonial missionaries had unwittingly been drawn. Far from subjecting the natives to a higher truth, missionaries such as Van der Kemp followed in perhaps the most laudable aspect of Christian missionary tradition. Much like those early Jewish Christians in Antioch, they suspended what they might have thought they knew about the truth and how it should be communicated in order to rather make accessible the Christian message to the real felt needs of the people they were ministering to.

\section{FROM INTERNAL DIALOGUE TO REAL DIALOGUE}

Mabiala Kenzo states that Africa as a postcolony, 'is made up of a plurality of religious spheres and arenas...' (Kenzo 2004: 251). Korea is, of course, also a postcolony, although having been colonized by another East Asian nation, Japan, not in the same way that Africa is. Nevertheless, through missionary work, English teachers, and other Euro-American influences, including the ongoing US military presence, South Korea is not really the monoculture it still sometimes imagines itself to be. The postcolonial concept of hybridity, which Kenzo describes in relation to the Nigerian context, is equally applicable to both South Korean and Southern African Zionist Christianity. Kenzo states: 'Whether observed as the state of hybridity, or encouraged as the process of hybridization, the notion is predicated on the premise that identities - subjective or otherwise - are historically, culturally, and politically constructed processes rather than given essences' (Kenzo 2004: 260).

I think that most non-sect-like social identities in our world have become hybridized to some degree. Neither is this a recent phenomenon. In terms of Christianity as a culture crossing world religion, hydridity could describe the situation at least as early as the synthesis achieved by the early Christians in the city of Antioch. I would argue that Christianity has never and nowhere recovered it's 'purity,' if it ever had that. Ever since Antioch it has been 'tainted' by hybridity, and always will be, the objections of fundamentalists and insisters on 'orthodoxy' notwithstanding.

Postcolonial contexts subjected to rapid, recent, social change such as found in South Korea and much of sub-Saharan Africa provide the kind of micro-cosmic backgrounds from which one 
could acutely observe this kind of process in contemporary setting. They serve as good examples of what has been going on, also at other times and in other places in the history of Christianity.

For Christians, accepting our own religious hybridity, acknowledging the inner interreligious dialogue is a necessary part of the process towards active meaningful dialogue with the adherents of other faiths. The potential problem would be that such inner interreligious dialogue, when recognized, could be misidentified as 'sinful idolatry,' and as such maligned or denied.

A far more honest and constructive approach would be to bring such inner dialogue to the surface, and prayerfully continue to engage with it. What Christian communities need to realize is that their religious 'commitment' cannot preclude or overcome their own hybridity. Hybridity is a messy business, but it illustrates the reality of human existence. Ideals of 'pureness,' on the other hand, are where the real danger of sinful idolatry resides. Christians who have hoodwinked themselves into believing that they are 'untainted' by other religions/ideologies, who claim orthodoxy for themselves to the exclusion of those who are not in their inner circle, are simply Christians who have not 'woken up' to their inner dialogue.

The reason for waking up to and confronting the fullness of one's religious identity is that no meaningful outward dialogue could be possible without it. As Jerald Gort states, 'Serious religious identity is the very foundation of authentic interreligious dialogue. In order to have proper dialogue at any level, the partners have to know where they stand' (Gort 2008: 759).

Knowing where one stands, acknowledging one's inner interreligious dialogue is not a contradiction of religious commitment, but an affirmation thereof, even if it entails an acceptance of the paradoxical nature of the phenomenology of Christianity.

Proper self-understanding is a prerequisite for understanding and engaging with the 'Other'. It should be a small step to move from acknowledgment of the inner dialogue to honest and humble outward dialogue in the pursuit of truth, love, and justice for all creation.

\section{Bibliographical note}

Retief Müller is a South African teaching in Korea. He is Assistant Professor of Christian Studies at Keimyung University in the city of Daegu. His research interests include southern African and Korean Christianities and his forthcoming book, African Pilgrimage - Ritual Travel in South Africa's Christianity of Zion, is due to be published by Ashgate in October 2011.

\section{REFERENCES}

Brah, Avtar and Coombes, Annie (Eds). 2000. Hybridity and its Discontents: Politics, Science, Culture. London: Routledge.

Buswell, Robert E. Jr. and Lee, Timothy S. (Eds.) 2006. Christianity in Korea. Honolulu: University of Hawaii Press.

Gort, J.D. 2008. 'The search for interreligious connivance, ongoing challenge and charge' Verbum et Ecclesia 29, 3:744-763.

Grayson, James Huntley. 2006. 'A Quarter-Millennium of Christianity in Korea.' In Christianity in Korea, edited by Robert E. Buswell Jr. and Timothy S. Lee, 7-25. Honolulu: University of Hawaii Press.

Hastings, Adrian. 1994. The Church in Africa 1450-1950. Oxford: Oxford University Press.

Horton, Robin. 1971. 'African Conversion'. Africa XLI, 2:85-108.

Jang, Hyung Chull. 2006. 'The Rapid Growth of Protestant Christianity in Korea and the Emergence of Cultural Hybridity within it.' Modern Believing 47, no 1 Ja: 43-53.

Kenzo, Mabiala Justin-Robert. 2004. 'Religion, hybridity, and the construction of reality in postcolonial Africa,' Exchange 33, 3:244-268.

Keum, Jang-tae. 2000. Confucianism and Korean Thoughts, Korean Studies Series No. 10. Jimoondang Publishing Company.

Kim, Young-Gwan. 2000. 'The Confucian-Christian Context in Korean Christianity,' B.C. Asian Review 13, Spring: 70-91. 
Kirk, J. Andrew. 2000. What is Mission: Theological Explorations. Minneapolis: Fortress Press.

Krige, E. J. and J. D. Krige. 1943. The Realm of a Rain-Queen: A Study of the Pattern of Lovedu Society. London: Oxford University Press.

Lee, Timothy S. 2006. 'Beleaguered Success: Korean Evangelicalism in the Last Decade of the Twentieth Century.' In Christianity in Korea, edited by Robert E. Buswell Jr. and Timothy S. Lee, 330-350. Honolulu: University of Hawaii Press.

Mönnig, H.O. 1967. The Pedi. Pretoria: J. L. van Schaik.

Müller, R. 2008. 'Rain rituals and hybridity in Southern Africa.' Verbum et Ecclesia 29, 3:819-831

Nchabeleng, Solomon Pitsadi. 1983. 'The Zion Christian Church of Ignatius Lekganyane: Its Origin, History and Character in Comparison with Reformed and with Traditional Structures.' B.D. thesis, University of the North.

Oak, Sung-Deuk. 2006. 'Chinese Protestant Literature and Early Korean Protestantism.' In Christianity in Korea, edited by Robert E. Buswell Jr. and Timothy S. Lee, 72-93. Honolulu: University of Hawaii Press.

Oh, Kang-Nam. 2006. 'The Christian-Buddhist Encounter in Korea.' In Christianity in Korea, edited by Robert E. Buswell Jr. and Timothy S. Lee, 371-391. Honolulu: University of Hawaii Press.

Parrinder, Geoffrey. 1976. African Traditional Religion. New York: Harper \& Row.

Phan, Peter C. 2003. 'Multiple Religious Belonging: Opportunities and Challenges for Theology and Church.' Theological Studies 64:495-519.

Ramadubu, Dikarabo. 2005. 'ZCC Pilgrims descend on Gaborone.' Botswana Guardian. Gaborone, 18-24 November.

Sanneh, Lamin. 1995. Translating the Message: The Missionary Impact on Culture. Maryknoll: Orbis Books.

Scott, Peter Manley. 2004. 'We Have Never Been Gods: Transcendence, Contingency and the Affirmation of Hybridity.' Ecotheology 9.2:199-220.

Schapera, I. 1971. Rainmaking Rites of Tswana Tribes. Leiden: Afrika-Studiecentrum.

Tran, Jonathan. 2008. 'Transgressing Borders: Genetic Research, Immigration, and Discourses of Sacrifice.' Journal of the Society of Christian Ethics, 28, 2:97-116.

Tomkins, Stephen. 2005. A Short History of Christianity. Grand Rapids: Eerdmans.

Walls, Andrew F. 2002. The Cross-Cultural Process in Christian History. Maryknoll: Orbis Books. .1996. The Missionary Movement in Christian History: Studies in the Transmission of Faith. Maryknoll: Orbis Books.

\section{KEY WORDS}

interfaith-dialogue

Christianity

Africa

Korea

hybridity

history

plurality

theology

TREFWOORDE

Christendom

Intergodsdienstige dialoog

Afrika

Korea

geskiedenis

pluraliteit

teologie

\author{
KONTAKBESONDERHEDE \\ Dr Retief Müller \\ Daegu, Dalseo-Gu, \\ Yeongsan-2-dong 414-1 \\ Yeongnam-woobang town \\ 101dong 1407 ho \\ 704744 \\ Republic of Korea \\ E-posadres: retief.muller@ \\ alum.ptsem.edu
}

